\title{
COMPARISON OF FOUR ANTIBIOTICS FOR INACTIVATING LEPTOSPIRES IN BULL SEMEN DILUTED IN EGG YOLK EXTENDER AND EXPERIMENTALLY INOCULATED WITH LEPTOSPIRA SANTAROSAI SEROVAR GUARICURA
}

\author{
Fabiana Miraglia; Zenaide Maria Morais; Adriana Cortez; Priscilla Anne Melville; Maria Fernanda Vianna Marvullo; \\ Leonardo José Richtzenhain; José Antonio Visintin; Silvio Arruda Vasconcellos*
}

Faculdade de Medicina Veterinária e Zootecnia, Universidade de São Paulo, São Paulo, SP, Brasil

Submitted: February 04, 2003; Returned to authors for corrections: April 14, 2003; Approved: May 05, 2003

\begin{abstract}
Inactivation of leptospires in pools of semen from three Holstein Friesian bulls, collected in an artificial vagina, was investigated. Spermatic concentration was adjusted in egg yolk citrate extender, submitted to the following treatments: A (control; without antibiotics); B (penicillin, 1,000 UI/mL - streptomycin, 1,000 $\mu \mathrm{g} / \mathrm{mL}$ );

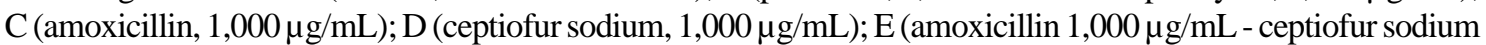
$1,000 \mu \mathrm{g} / \mathrm{mL})$. Leptospires $\left(2.0 \times 10^{6}\right.$ leptospires $\left./ \mathrm{mL}\right)$ were added into the diluted semen. Recovery of leptospires was obtained in modified EMJH semi-solid medium with and without antibiotics. The antibiotics in the concentrations used did not affect means of percentage of progressive motility and individual progressive motility of spermatozoids. Penicillin-streptomycin presented the best results in leptospire inactivation (97.1\%). Amoxicillin, ceptiofur sodium and their combination at the concentrations studied presented poor results: $59.29 \% ; 32.5 \%$ and $60.36 \%$ of inactivation, being less effective in leptospire inactivation than penicillinstreptomycin.
\end{abstract}

Key words: Leptospires, semen, antibiotics, extender

\section{INTRODUCTION}

Bovine leptospirosis is spread worldwide and has been considered an important cause of economic losses in beef and dairy cattle industries (42).

Reproductive disorders include: abortion $(11,18,21)$, stillborn calves $(11,12,19,26,47)$, premature calving $(12,19)$, calving of weak calves (13), metritis and retained placenta (39); infertility, also in bulls (29), and sterility $(29,43)$.

Serovars of leptospires isolated, in Brazil, from cattle were: pomona (16); icterohaemorrhagiae (33); guaricura (44), goiano (46); hardjo and georgia (44).

Jones (22) and Sleight and Willians (37) mentioned leptospirosis transmission by artificial insemination or coitus. Ellis et al. (14) confirmed the presence of serovar hardjo in male and female bovine genital tract. Viability of leptospires in infected semen during cooling $\left(5^{\circ} \mathrm{C}\right)$ and freezing $\left(-196^{\circ} \mathrm{C}\right)$ was confirmed by Amatredjo and Campbell (7); Jones (22) and Kiktenko et al. (23).

Heinemann et al. (20) examined 20 bulls and found $80 \%$ of Leptospira spp positive samples using Polimerase Chain Reaction (PCR). All these samples were negative for leptospire when analyzed by culture, but most of them presented growth of microorganisms other than leptospires. Forty-five percent of these animals were positive by microscopic agglutination test (MAT). The authors concluded that bulls negative by MAT may not be free of leptospire infection even if semen cultures did not present any leptospire growth.

Considering that leptospirosis may be transmitted by artificial insemination and because of possible failures in the diagnosis in the bulls, research in semen treatment is needed to identify conditions that inactivate leptospires, but do not affect spermatozoa.

\footnotetext{
* Corresponding author. Mailing address: Departamento de Medicina Veterinária Preventiva e Saúde Animal, Av. Prof. Dr. Orlando Marques Paiva, 87.
} 05508-000, São Paulo, SP, Brasil. Fax: (+5511) 3091-7928. E-mail: savasco@usp.br 


\section{MATERIALS AND METHODS}

\section{Animals}

Semen donors were three Holstein Friesian bulls (two-years old) clinically normal and without evidences of leptospiral infection either by MAT with 24 serovars in blood serum and seminal plasma (32) or by PCR in semen (20).

\section{Semen extender and antibiotics}

Egg Yolk Citrate (EYC) extender (27) prepared with different antibiotics was used and concentrations were based on Almquist et al. (2,3,4,5), Arriola and Foote (8); Back et al. (9); Varner et al. (41). Experimental groups were as follows: A EYC without antibiotics (control); B - EYC, penicillin (ICN Biomedicals) (1,000 UI/mL) - streptomycin (FARMAVET) $(1,000$ $\mu \mathrm{g} / \mathrm{mL}$ ); C - EYC, amoxicillin (ICN Biomedicals) $(1,000 \mu \mathrm{g} / \mathrm{mL}$ ); D - EYC, ceptiofur sodium (Excenel - UPJHON) $(1,000 \mu \mathrm{g} / \mathrm{mL})$; E - EYC, amoxicillin $(1,000 \mu \mathrm{g} / \mathrm{mL})$-ceptiofur sodium $(1,000$ $\mu \mathrm{g} / \mathrm{mL})$.

\section{Semen samples}

Obtained by artificial vagina and mixed soon after collection in order to make a pool, maintained in a water bath at $38^{\circ} \mathrm{C}$. The number of spermatozoa was counted using a Newbauer chamber. The pool was diluted in EYC prepared with the above mentioned antibiotics, in order to achieve $8 \mathrm{x}$ $10^{7}$ spermatozoa $/ \mathrm{mL}$.

\section{Spermatozoa control}

Percentage of Progressive Motility (PMP) and Individual Progressive Motility (MPI) were evaluated soon after semen dilution and again after $24 \mathrm{~h}$ of storage at $5^{\circ} \mathrm{C}$. Comparison of these values was performed using ANOVA (18).

\section{Experimental inoculation of extended semen samples with Leptospires}

One millilitre of the extended semen pool was added to $2 \mathrm{~mL}$ of leptospire culture $\left(10^{6}\right.$ leptospires $\left./ \mathrm{mL}\right)$ cultivated in modified EMJH liquid medium $(6,40)$. The extended semen pool experimentally contaminated with $L$. santarosai serovar guaricura (44) was stored at $28-30^{\circ} \mathrm{C}$ for 30 minutes and then five ten-fold serial dilutions were prepared in modified EMJH (Difco Laboratories-USA) liquid medium.

\section{Trial for Leptospire isolation}

Five tubes of modified EMJH semi-solid ( $0.2 \%$ agar without antibiotics) and other five tubes of modified EMJH semi-solid with antibiotics (selective) (28) (0.2\% agar-5-fluorouracil - 300 $\mathrm{mg} / \mathrm{L}$ and nalidixic acid $20 \mathrm{mg} / \mathrm{L}$ ) were inoculated with each dilution of semen sample plus leptospires. For each culture tube the proportions of inoculum and medium were, respectively, 0.5 and $5 \mathrm{~mL}$. Incubation was performed at 28 to $30^{\circ} \mathrm{C}$. After $24 \mathrm{~h}$, samples in EMJH with antibiotics were subcultured in antibiotic free medium. Leptospire growth was confirmed by microscopic examination under darkfield ilumination. Cultures were maintained for six weeks and tubes presenting growth of microorganisms other than leptospire were discarded. The proportion of tubes presenting leptospire growth was compared by Fisher's Test (18).

\section{Control of microorganisms other than Leptospire in semen}

Eight pools of non-diluted frozen bovine semen were cultivated in $\mathrm{BHI}$ broth, and after $24 \mathrm{~h}$ at $37^{\circ} \mathrm{C}$, they were cultivated on 5\% sheep blood agar, MacConkey agar and Saborauddextrose agar. Blood agar and MacConkey plates were incubated at $37^{\circ} \mathrm{C}$ and bacterial growth was observed after 24 and $72 \mathrm{~h}$; Saboraud plates were kept at room temperature for at least seven days. Microorganisms were identified by macro-microscopical morphology and biochemical characteristics and were classified according to Murray et al. (30) and Krieg and Holt (31). A fresh pool of semen was cultivated in 5\% sheep blood agar, MacConkey agar and Saboraud-dextrose agar, and microorganisms isolated were identified as described for the pools of frozen semen.

\section{RESULTS}

Table 1 presents the results of spermatozoa pool examination according to the groups of antibiotics included in the EYC extender. Mean PMP and mean MPI (0-5) were evaluated soon after semen dilution (TOh) and again 24h after semen dilution (T24h). There were no significant differences between the five treatments in the different evaluation times.

Table 2 presents the isolation of leptospire according to the media used and the antibiotics included in EYC. The best results were obtained with EYC with penicillin-streptomycin and media with antibiotics for isolation in the first 24 hours after sample seeding.

Fig. 1 presents the percentages of leptospire growth reduction in the different treatments, considering as $100 \%$ of growth the number of positive tubes in the samples diluted in EYC without antibiotics (A). It was possible to observe that results were, in decreasing order, B: $97.11 \%$; E: $60.36 \%$; C: $59.29 \%$ and $\mathrm{D}: 32.50 \%$.

Table 3 presents microorganisms other than leptospire, isolated from eight batches of bovine semen. From seven frozen batches examined, five presented growth of Corynebacterium sp; four presented Bacillus sp; two, Streptococcus sp; and one, Micrococcus sp. In one culture of fresh semen, growth of Proteus mirabilis occurred. There was no growth of molds and yeasts.

MAT (24 serovars) for anti-leptospire agglutinines in seminal plasma of all semen pools investigated presented negative results. 
Table 1. Mean percentage of progressive motility (PMP) and mean progressive individual motility (MPI) of spermatozoa from semen pools, according to the time of evaluation and to the type of antibiotic added to the egg-yolk-citrate extender. São Paulo, 2003.

\begin{tabular}{|c|c|c|c|c|}
\hline \multirow[t]{2}{*}{ Groups } & \multicolumn{2}{|c|}{$\mathrm{PMP}$ mean $\pm \mathrm{SD}$} & \multicolumn{2}{|r|}{ MPI mean \pm SD } \\
\hline & TOh & T24h & T0h & T24h \\
\hline A & $77.27 \pm 10.09^{\text {(a) }}$ & $64.54 \pm 12.13^{(\mathbf{b})}$ & $3.63 \pm 0.50^{(\mathrm{c})}$ & $2.90 \pm 0.70^{(\mathrm{d})}$ \\
\hline B & $74.09 \pm 9.17^{(\mathrm{a})}$ & $66.81 \pm 8.44^{(\mathbf{b})}$ & $3.72 \pm 0.46^{(\mathrm{c})}$ & $3.00 \pm 0.63^{(\mathrm{d})}$ \\
\hline $\mathbf{C}$ & $72.72 \pm 10.80^{\text {(a) }}$ & $66.36 \pm 13.80^{(\mathbf{b})}$ & $3.18 \pm 0.75^{(\mathrm{c})}$ & $2.90 \pm 0.70^{(d)}$ \\
\hline D & $76.36 \pm 10.74^{\text {(a) }}$ & $58.18 \pm 23.79^{(\mathbf{b})}$ & $3.72 \pm 0.46^{(\mathrm{c})}$ & $3.36 \pm 0.50^{(\mathrm{d})}$ \\
\hline $\mathbf{E}$ & $77.72 \pm 9.84^{\text {(a) }}$ & $60.45 \pm 22.41^{(\mathbf{b})}$ & $3.81 \pm 0.40^{(\mathrm{c})}$ & $2.81 \pm 0.87^{(\mathrm{d})}$ \\
\hline
\end{tabular}

A: EYC without antibiotics (control); B: EYC with penicillin-streptomycin; C: EYC with amoxicillin; D: EYC with ceptiofur sodium; E: EYC with amoxicillin-ceptiofur sodium; (a) (b)(c)(d) (e): means with same superscripts, in the same column, do not differ $(\mathrm{P}>0.01) /$ ANOVA: $\mathrm{P}=0.7415$; ANOVA: $\mathrm{P}=0.7099$ /KRUSKAL-WALLIS: $\mathrm{P}=0.9729$; ANOVA: $\mathrm{P}=0.0566$; ANOVA: $\mathrm{P}=0.3952$, respectively.

Table 2. Number of cultures performed for leptospire isolation in bull semen samples experimentally contaminated with the L.santarosai serovar guaricura, according to the type of isolation medium and the antibiotics included in the egg-yolkcitrate extender. São Paulo, 2003.

\begin{tabular}{|c|c|c|}
\hline Groups & $\mathbf{E M J H}^{(1)}$ & EMJH selective ${ }^{(1)(2)}$ \\
\hline & $\begin{array}{c}\text { Porcentage of } \\
\text { positive cultures } \\
\text { (positive number/total) }\end{array}$ & $\begin{array}{c}\text { Porcentage of positive } \\
\text { positive cultures } \\
\text { (positive number/total) }\end{array}$ \\
\hline $\mathbf{A}$ & $87.6(99 / 113)^{[x]}$ & $89.0(178 / 200)$ \\
\hline B & $5.1(7 / 136)$ & $0.0(0 / 212)$ \\
\hline $\mathbf{C}$ & $43.8(63 / 144)^{[y]}$ & $28.1(55 / 196)^{[z]}$ \\
\hline D & $78.8(100 / 127)^{[\mathrm{x}]}$ & $45.4(99 / 218)$ \\
\hline $\mathbf{E}$ & $44.0(62 / 141)^{[y]}$ & $26.1(57 / 218)^{[z]}$ \\
\hline
\end{tabular}

A: EYC without antibiotics (control); B: EYC with penicillinstreptomycin; C: EYC with amoxicillin; D: EYC with ceptiofur sodium; E: EYC with amoxicillin-ceptiofur sodium; (1) modified medium with $0.2 \%$ agar; (2) with nalidixic acid and 5-Fluorouracil; ${ }^{[x][y][z]}$ same superscripts, in the same columns, do not differ; $\mathrm{P}<0.0856, \mathrm{P}=1.000, \mathrm{P}=0.7397$, respectively.

Table 3. Microorganisms other than leptospire, found in bovine semen, according to the batch. São Paulo, 2003.

\begin{tabular}{cl}
\hline Semen pool & \multicolumn{1}{c}{ Microorganisms } \\
\hline $01^{(\mathbf{1})}$ & Corynebacterium $\mathrm{sp}$ \\
$02^{(\mathbf{1})}$ & Corynebacterium $\mathrm{sp} /$ Streptococcus $\mathrm{sp}$ \\
$03^{(\mathbf{1})}$ & Bacillus $\mathrm{sp} /$ Corynebacterium $\mathrm{sp}$ \\
$04^{(\mathbf{1})}$ & Bacillus $\mathrm{sp} /$ Corynebacterium $\mathrm{sp}$ \\
$05^{(\mathbf{1})}$ & Bacillus $\mathrm{sp} /$ Corynebacterium $\mathrm{sp}$ \\
$06^{(\mathbf{1})}$ & Bacillus $\mathrm{sp} /$ Corynebacterium $\mathrm{sp}$ \\
$07^{(\mathbf{1})}$ & Micrococcus $\mathrm{sp} /$ Streptococcus $\mathrm{sp}$ \\
$08^{(\mathbf{2})}$ & Proteus mirabilis \\
\hline
\end{tabular}

(1) frozen semen samples; (2) fresh semen sample.

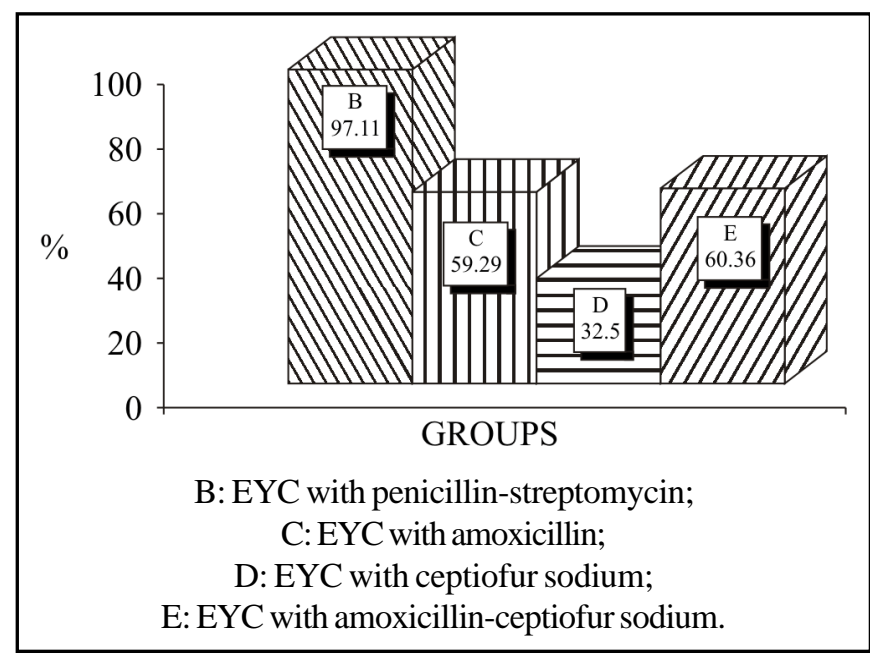

Figure 1. Reduction of leptospiral growth taking group A (EYC free of antibiotics) as $100 \%$ of growth, according to the treatment.

\section{DISCUSSION}

Mean PMP and MPI, determined in EYC extenders containing antibiotics in the concentrations tested, presented no significant differences. EYC with penicillin-streptomycin presented results in agreement with those by Almquist $(2,3,4,5)$ who did not find that these antibiotics could cause any spermatozoa impairment. Arriola and Foote (8) reached the same conclusion with equine semen diluted in egg-yolk-tris extender including penicillinstreptomycin or amikacyn. Varner (41) applied the milk-glycose extender to cooled equine semen including ceptiofur sodium and other antibiotics. Back (9) obtained similar results with equine semen diluted in egg-yolk-tris extender including gentamicin, kanamycin, lincomycin, penicillin and streptomycin.

For leptospire isolation, treatment with penicillinstreptomycin presented better results than the other treatments. The inactivating ability of these two antibiotics was also 
reported for other serovars, such as pomona $(7,22,23,31)$. The efficiency of streptomycin alone was also reported for serovar sejroe (45). Hoag and Bell (21) described the growth of pure cultures of the serovars sejroe, pomona, grippotyphosa and icterohaemorrhagiae in media prepared with streptomycin.

Although the inclusion of penicillin-streptomycin in EYC inactivated all leptospire cultures seeded in selective isolation media (0/212), the occurence of 5.1\% (7/136) positive tubes in non-selective media shows that semen collected from infected animals and diluted in extenders prepared with these antibiotics may contain live leptospires. Bryan and Boley (10) also found surviving leptospires in bull semen diluted in extender prepared with penicillin, streptomycin and sulfanilamide.

Although amoxicillin $(1,000 \mu \mathrm{g} / \mathrm{mL})$ showed poor ability to inactivate leptospire serovar guaricura in bull semen, other concentrations of this antibiotic should be investigated. Smith (38) has described a strong effect of amoxicillin on the "in vivo" treatment of kidney carriers, in cattle infected by the serovar hardjo.

The treatment of bull semen samples with ceptiofur sodium $(1,000 \mathrm{mg} / \mathrm{mL})$ was not effective for leptospire inactivation in $57.7 \%$ (199/345) of positive cultures. Alt and Bolin (1) did not find any results using cephalosphorin in the control of kidney carriers in swine infected by serovar pomona. However, in hamsters experimentally infected with the same serovar, Santos et al.(34) observed that this antibiotic presented a strong ability to control the disease.

The presence of positive leptospire cultures in semen samples diluted in extender prepared with penicillin (1,000 UI/ $\mathrm{mL})$ and streptomycin $(1,000 \mu \mathrm{g} / \mathrm{mL})$ would suggest that other trials with higher concentrations of these two antibiotics should be performed. However, Almquist et al. $(3,4,5)$ and Arriola and Foote (8) observed that concentrations higher than these led to significant losses in the progressive motility of bull spermatozoa.

Other antibiotic associations must be investigated, like those done by Golsteyn-Thomas et al. (17), who got good results in the inactivation of serovars pomona and hardjobovis with an extender that included gentamicin, tylosin, lincomycin and spectinomycin.

The number of tubes presenting leptospire growth in bovine semen samples experimentally contaminated with serovar guaricura was higher in selective modified EMJH semi-solid medium than in the non-selective medium. This result was attributed to the natural presence of microorganisms other than leptospires in semen samples. This was also observed by Heinemann et al. (20); Schönberg (35) and Schönberg et al. (36). In the present study, in fresh individual semen samples, positive cultures for Proteus mirabilis were observed. In frozen pools, the microorganisms isolated were Corynebacterium $\mathrm{sp}$, Bacillus sp, Streptococcus sp and Micrococcus sp, suggesting that environmental microorganisms may enter the samples during the preparation of semen pools.

\section{ACKNOWLEDGMENTS}

The authors wish to thank FAPESP for financial support.

\section{RESUMO}

\section{Comparação de quatro antibióticos para inativar leptospiras em sêmen bovino diluído em gema-citrato e experimentalmente contaminado com Leptospira santarosai sorovar guaricura}

A inativação de leptospiras em misturas de sêmen, obtidas através de vagina artificial, de três touros holandeses, foi estudada. A concentração espermática foi ajustada em diluidor gema-citrato utilizando os seguintes tratamentos: A (controle; sem antibióticos); B (penicilina, $1000 \mathrm{UI} / \mathrm{mL}$ - estreptomicina, $1000 \mu \mathrm{g} / \mathrm{mL}$ ); C (amoxicilina, $1000 \mu \mathrm{g} / \mathrm{mL}$ ); D (ceftiofur sódico, $1000 \mu \mathrm{g} / \mathrm{mL}$ ); E (amoxicilina $1000 \mu \mathrm{g} / \mathrm{mL}$ - ceftiofur sódico 1000 $\mu \mathrm{g} / \mathrm{mL})$. Leptospiras $\left(2,0 \times 10^{6}\right.$ leptospiras $\left./ \mathrm{mL}\right)$ foram adicionadas ao sêmen diluído. A recuperação das leptospiras foi obtida em meio EMJH modificado semi-sólido, com e sem antibióticos. As médias da porcentagem de motilidade progressiva e a de motilidade individual progressiva dos espermatozóides não foram afetadas pelos antibióticos nas concentrações usadas. Penicilina-estreptomicina apresentou os melhores resultados na inativação das leptospiras $(97.1 \%)$. Amoxicilina, ceftiofur sódico e suas combinações, nas concentrações estudadas, apresentaram resultados insatisfatórios: $59.29 \% ; 32.5 \%$ e $60.36 \%$ de inativação, sendo menos efetivos na inativação das leptospiras do que penicilina-estreptomicina.

Palavras-chave: Leptospiras, sêmen, antibióticos, diluidor

\section{REFERENCES}

1. Alt, D.P.; Bolin, C.A. Preliminary evaluation of antimicrobial agents for treatment of Leptospira interrogans serovar pomona infection in hamsters and swine. Am. J. Vet. Res., 57: 59-62, 1996.

2. Almquist, J.O.; Glantz, P.J.; Shaffer, H.E. The effect of a combination of penicillin and streptomycin upon the livability and bacterial content of bovine semen. J. Dairy Sci., 32: 543-548, 1949.

3. Almquist, J.O.; Glantz, P.J.; Thorp, W.T.S. The effect of streptomycin upon the livability, and bacterial content of bovine semen. J. Dairy Sci., 31: 501-507, 1948.

4. Almquist, J.O.; Thorp, W.T.S.; Knodt, C.B. The effect of penicillin upon the livability, fertility and bacterial content of bull semen. $J$. Animal Sc., 5: 400, 1946.

5. Almquist, J.O.; Thorp, W.T.S.; Knodt, C.B. The effect of penicillin upon the livability, glycolysis and bacterial content of bovine semen. J. Dairy Sci., 31: 11-19, 1948.

6. Alves, C.J; Vasconcellos, S.A.; Camargo, C.R.A.A.; Morais, Z.M. Influência de fatores ambientais sobre a proporção de caprinos soro reatores para a leptospirose em cinco centros de criação do estado da Paraíba, Brasil. Arquiv. Inst. Biol., 63: 11-18, 1996.

7. Amatredjo, A.; Campbell, R.S.F. Bovine leptospirosis. Vet. Bull., 45: 875-891, 1975. 
8. Arriola, J.; Foote, R.H. Effects of amikacin sulfate on the motility of stallion and bull spermatozoa at different temperatures and intervals of storage. J. Animal Sci., 54: 1105-1110, 1982.

9. Back, D.G.; Pickett, B.W.; Voss, J.L.; Seidel, G.E. Effect of antibacterial agents on the motility of stallion spermatozoa at various storage times, temperatures and dilution ratios. J. Animal Sci., 41: 137-143, 1975.

10. Bryan, N.S.; Boley, L.E. Studies on leptospirosis in domestics animals. IV. Survival of Leptospira pomona in bovine semen extender. Mich. State Univ. Vet., 16: 27-29 and 55, 1955.

11. Cascelli, E.S.; Fabris, M.; Martinez, E.S.; Saravi, M.A.; Cachione, R.A. Un brote de leptospirosis en terneros de la Prov. De Buenos Aires y su control vacunal, Rev. Med. Vet., 60: 258-262, 1979.

12. Eaglesome, M.D.; Garcia, M.M. Microbiological agents associated with bovine genital infections and semen. Part I. Brucella abortus, Leptospira, Campylobacter foetus and Tritrichomonas foetus. Vet. Bull., 62: 743-744; 751-758, 1982.

13. Ellis, W.A. Leptospirosis as a cause of reproductive failure. Vet. Clin. North Am.: Food Ani. Pract., 10: 463-479, 1994.

14. Ellis, W.A.; Cassels, J.A.; Doyle, J. Genital leptospirosis in bulls Vet Record, 118: 333, 1986.

15. Ellis, W.A.; Neill, S.D.; O’ Brien, J.J.; Neill, S.; Hanna, J.; Bryson, D.G. The isolation of a strain of leptospira serogroup icterohaemorragiae from anaborted bovine foetus. Brit. Vet. J., 133: 108-109, 1977

16. Freitas, D.C.; Lacerda, J.R.; Veiga, J.S.; Lacerda, J.P.G. Identificação da leptospirose bovina no Brasil. Rev. Fac. Med. Vet. Zootec. USP, 6: 81-83, 1957.

17. Golsteyn-Thomas, E.J.; Tanaka, E.E.; Druhan, S.E.; Howard, C.J. Determination of the viability of leptospires in processed bovine semen. In: Proceedings of International Leptospirosis Society, August 22-25, Marysville, Australia, 1999.

18. GRAPHPAD INSTAT 3. "Software" Instat Biostatistics (statistycal analisys). (1990-1993)

19. Guimarães, M.A.; Cortes, J.A.; Vasconcellos S.A.; Ito, F.H. Epidemiologia e controle da Leptospirose em bovinos. Papel do portador e seu controle terapêutico Com. Cient. Fac. Med. Vet. Zoo. USP, 6/7: 21-34, 1982.

20. Heinemann, M.B.; Garcia, J.F.; Nunes, C.M.; Morais, Z.M.; Gregori, F.; Cortez, A.; Vasconcellos, S.A.; Visintin, J.A.; Richtzenhain, L.J. Detection of leptospires in bovine semen by polymerase chain reaction. Aust. Vet. J., 77: 3-5, 1999.

21. Hoag, W.G.; Bell, W.B. In vitro studies on the action streptomycin upon five serotypes of Leptospira grown in two types of medium. Am. J. Vet. Res., 16: 251-254, 1955.

22. Jones, R.K. Study of the viability of Leptospira pomona in frozen extended bovine semen. J. Am. Vet. Med. Assoc., 133: 216-218, 1958

23. Kiktenko, V.S.; Balashov, N.G.; Rodina, V.N. Leptospirosis infecton through insemination of animals. J. Hyg. Epid. Microbiol. Immunol. 20: 207-213, 1976

24. Knott, S.G.; Dadswell, L.P. No outbreak of bovine abortions associated with leptospirosis. Aust. Vet. J., 46: 385-386, 1970.

25. Krieg, N.R.; Holt, J.C. Bergey's Manual of Clinical Bacteriology, Willians \& Wilkins, Baltimore, 1994. 2298 p.

26. Michina, S.W.; Campbell, R.S.F. The isolation of Leptospira sejroe from the kidneys of aborting cattle. Vet. Res., 84: 83-86, 1969.

27. Mies Filho, A. Inseminação Artificial, Sulina editor, Porto Alegre, 1987; 2: 736pp.

28. Miraglia, F.; Morais, Z.M.; Melville, P.A.; Dias, R.A.; Vasconcellos, S.A. Meio de EMJH modificado, seletivo, com 5-fluorouracil e ácido nalidíxico, para isolamento de leptospiras em amostras de sêmen bovino experimentalmente contaminadas com Leptospira santarosai sorovar guaricura. XXIX CONGRESSO BRASILEIRO DE MEDICINA VETERINÁRIA (CONBRAVET), Gramado, 2002. Anais.

29. Monke, D.R. Leptospirosis with special interest in bulls. Adv. An Breed., 1: 10-14, 1978.

30. Murray, P.R.; Baron, E.J.; Pfaller, M.A.; Tenover, F.C.; Yolker, R.H. Manual of clinical microbiology. Washington: Amer. Soc. Microbiol., 1999; $1773 \mathrm{p}$

31. Rodina, V.N.; Balashov, N.G. Leptospirosis infection of animals transmitted through insemination In: Proceedings of World Veterinary Congress, Mexico City, 1971; 19.

32. Santa Rosa, C.A. Diagnóstico laboratorial das leptospiroses. Rev. Microbiol., 1: 97-109, 1970.

33. Santa Rosa, C.A.; Castro, A.F.P.; Troise, C. Leptospirose bovina. Inquérito sorológico na região de Campinas. Arq. Inst. Biol., 28 169-173, 1961.

34. Santos, G.O.; Cardoso, F.; Vasconcellos, S.A.; Morai,s Z.M.; Cortez, A.; Fávero, A.C.M.; Miraglia, F.; Pinheiro, S.R.; Amos, C.A.A. Emprego do ceftiofur sódico ou da estreptomicina para a terapia da leptospirose em hamsters experimentalmente infectados com o sorovar pomona. Supl. Arq. Inst. Biol., 67: 1-145, 2000.

35. Schönberg, A. Studies on the effect of antibiotic substances on leptospires and their cultivation from material with a high bacterial count. Zent. Bakt. Parasit. Infekt. Hyg., 249: 400-406, 1981.

36. Scönberg, A.; Kämpe, U.; Rohloff, D. Methods for the detection of leptospires in sperm samples of boar. Berl. Münch. Tierärztl Wochenschr, 93: 166-171, 1980.

37. Sleight, S.D.; Willians, J.A. Transmission of bovine leptospirosis by coition and Artificial Insemination. J. Am. Vet. Med. Assoc., 138: 151-152, 1961

38. Smith, C.R.; Corney, B.G.; MacGowan, M.R.; McClintock, C.S.; Ward, W.; Ketterer, P.J. Amoxycillin as na alternative to dihydroetreptomycin sulphate for treating cattle infected with Leptospira borgpetersenii serovar hardjo. Aust. Vet. J., 75: 818-821, 1997.

39. Stoenner, H.G.; Crews, F.W.; Crouse, A.E.; Taschner, L.E.; Johnson, C.E.; Wohleb, J. The epizootiology of bovine leptospirosis in Washington. J. Amer. Vet. Med. Assoc., 129: 251-259, 1956.

40. Turner, L.H. Leptospirosis III. Maintenance, isolation and demonstration of leptospiras. Trans. Royal Soc. Trop. Med. Hyg., 64: 623-646, 1970.

41. Varner, D.D.; Scanlan, C.M.; Thompson, J.A.; Brumbaug, G.W.; Blanchard, T.L.; Carlton, C.M.; Jonhson, L. Bacteriology of preserved stallion semen and antibiotics in semen extenders. Theriogenol., 50: 559-573, 1998.

42. Vasconcellos, S.A. Leptospirose animal. In: Encontro Nacional em Leptospirose, Rio de Janeiro, 1993.

43. Vasconcellos, S.A.; Ito, F.H.; Cortes, J.A Base para prevenção da brucelose animal. Comun. Cient. Fac. Med. Vet. Zoo. USP, 11: 25 36, 1987.

44. Vasconcellos, S.A.; Oliveira, J.C.F.; Morais, Z.M.; Baruselli, P.S. Amaral, R.; Pinheiro, S.; Ferreira, F.; Ferreira-Neto, J.S.; Schönberg, A.; Hartskeerl, R.A. Isolation of Leptospira santarosai, serovar guaricura from buffaloes (Bubalus bubalis) in Vale do Ribeira, São Paulo, Brazil. Brazil. J. Microbiol., 32: 298-300, 2001.

45. Warren, G.H.; Wilson, B.B. In vitro studies on the action of streptomycin upon five serotypes of Leptospira grown in two types of medium. Am. J. Vet. Res., 16: 251-254, 1955.

46. Yanaguita, R.M. Contribuição ao Estudo da leptospirose bovina. Isolamento de dois novos sorotipos no sorogrupo hebdomadis: sorotipos guaicurus e goiano. São Paulo, 1972, 71p. (Ph. D. Thesis. Instituto de Ciências Biomédicas. USP)

47. Zamora, J.; Riedemann, S.A. Leptospirosis. Consideraciones sobre control y tratamiento Arch. Med. Vet., 8: 131-136, 1976. 